\title{
Assessing the prospective resource base for enhanced geothermal systems in Europe
}

\author{
J. Limberger ${ }^{1}$, P. Calcagno ${ }^{2}$, A. Manzella ${ }^{3}$, E. Trumpy ${ }^{3}$, T. Boxem ${ }^{4}$, M. P. D. Pluymaekers ${ }^{4}$, and \\ J.-D. van Wees ${ }^{1,4}$ \\ ${ }^{1}$ Department of Earth Sciences, Utrecht University, Utrecht, the Netherlands \\ ${ }^{2}$ BRGM, Orléans, France \\ ${ }^{3}$ Institute of Geosciences and Earth Resources, CNR, Pisa, Italy \\ ${ }^{4} \mathrm{TNO}$ - Geological Survey of the Netherlands, Utrecht, the Netherlands \\ Correspondence to: J. Limberger (j.limberger@uu.nl)
}

Received: 22 June 2014 - Accepted: 11 November 2014 - Published: 23 December 2014

\begin{abstract}
In this study the resource base for EGS (enhanced geothermal systems) in Europe was quantified and economically constrained, applying a discounted cash-flow model to different techno-economic scenarios for future EGS in 2020, 2030, and 2050. Temperature is a critical parameter that controls the amount of thermal energy available in the subsurface. Therefore, the first step in assessing the European resource base for EGS is the construction of a subsurface temperature model of onshore Europe. Subsurface temperatures were computed to a depth of $10 \mathrm{~km}$ below ground level for a regular 3-D hexahedral grid with a horizontal resolution of $10 \mathrm{~km}$ and a vertical resolution of $250 \mathrm{~m}$. Vertical conductive heat transport was considered as the main heat transfer mechanism. Surface temperature and basal heat flow were used as boundary conditions for the top and bottom of the model, respectively. If publicly available, the most recent and comprehensive regional temperature models, based on data from wells, were incorporated.

With the modeled subsurface temperatures and future technical and economic scenarios, the technical potential and minimum levelized cost of energy (LCOE) were calculated for each grid cell of the temperature

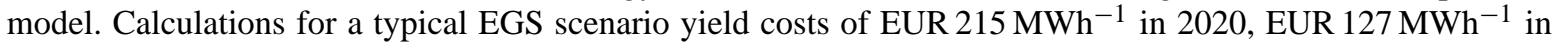
2030, and EUR $70 \mathrm{MWh}^{-1}$ in 2050. Cutoff values of EUR $200 \mathrm{MWh}^{-1}$ in 2020, EUR $150 \mathrm{MWh}^{-1}$ in 2030, and EUR $100 \mathrm{MWh}^{-1}$ in 2050 are imposed to the calculated LCOE values in each grid cell to limit the technical potential, resulting in an economic potential for Europe of $19 \mathrm{GW}_{\mathrm{e}}$ in $2020,22 \mathrm{GW}_{\mathrm{e}}$ in 2030 , and $522 \mathrm{GW}_{\mathrm{e}}$ in 2050. The results of our approach do not only provide an indication of prospective areas for future EGS in Europe, but also show a more realistic cost determined and depth-dependent distribution of the technical potential by applying different well cost models for 2020, 2030, and 2050.
\end{abstract}

\section{Introduction}

Enhanced or engineered geothermal systems (EGS) have increased the number of locations that could be suitable for geothermal power production. In the past, geothermal power production was limited to shallow high-enthalpy reservoirs $\left(>180^{\circ} \mathrm{C}\right)$ in volcanic areas, whereas current EGS technologies facilitate exploitation of medium-enthalpy reservoirs $\left(80-180^{\circ} \mathrm{C}\right)$ situated at greater depth in sedimentary basins or in the crystalline basement.
Breakthroughs in binary power plant technology (e.g., organic Rankine cycle and Kalina plants) have enabled the use of medium enthalpy heat sources by using a binary working fluid to power the turbines (Astolfi et al., 2014a, b; Coskun et al., 2014). Innovations from the oil and gas industry such as directional drilling and techniques to enhance the reservoir properties, including hydraulic stimulation, provide a way to exploit these deeper reservoirs and, in theory, decrease the dependency on their natural permeability (Huenges, 2010). 
Consequently, these developments should allow for more flexibility and a significant increase in the number of suitable locations for geothermal power production. In practice, development of EGS is not straightforward and so far in Europe most of the EGS power plants currently operational are limited to areas around the failed rift system of the Rhine Graben and the Molasse Basin of the northern Alpine foreland (e.g., Gérard et al., 2006; Baumgärtner, 2012; Breede et al., 2013).

For EGS and other geothermal systems, flow rate $Q$ and the temperature of the reservoir fluid $T$ are the key parameters that control the power output $P$ of a geothermal power plant. For large-scale resource assessments the temperature in the subsurface is a relatively convenient parameter to work with. In most nonvolcanic areas in Europe, conduction is the dominant heat transfer mechanism in the lithosphere. Temperatures can therefore be estimated with a steady-state conductive model based on assumptions and inferences on the thermal conductivity structure of the lithosphere, the heat flow at the base of the lithosphere, and on the content of heat-producing elements in the lithosphere (Cloetingh et al., 2010).

$Q$ depends strongly on the (enhanced) reservoir permeability, determined by lithological properties such as porosity, and the presence, distribution and permeability of natural fractures. These properties are dynamic and will change when the area of the reservoir is subjected to changes in temperature, pressure and the state of stress. Therefore, the reservoir permeability can easily vary by several orders of magnitude. Without knowledge of the geological history and thorough reservoir characterization, extreme caution should be taken when predicting $Q$ for a prospect.

This European resource assessment for EGS was conducted as part of the GeoElec European project to favor the development of geothermal electricity production in Europe (Dumas et al., 2013). The study covers the continental Europe plus the UK, Ireland, and Iceland but does not take into account the European overseas territories.

The first large-scale resource assessment for EGS was conducted for the United States (Tester, 2006; Blackwell et al., 2007). More recently, an updated resource assessment for the United States from (Williams et al., 2008) has been combined with a development cost model to create resource supply curves (Augustine et al., 2010; Augustine, 2011).

The most important input for the resource assessment in this study is a 3-D subsurface temperature model of Europe. The basic methodology of this temperature model is given in Sect. 2. The most recent and comprehensive regional temperature models available are incorporated, and combined with lithosphere-scale models to construct the model geometry and distribute thermal properties.

For the resource assessment of Europe we propose an approach similar to (Augustine et al., 2010) that extends the protocol from Beardsmore et al. (2010). As a starting point, the electrical power that could be technically produced from the theoretical capacity of thermal energy stored in the subsurface was estimated from the subsurface temperature model, with a set of assumptions such as flow rate, plant lifetime, conversion efficiency, and a recovery factor. This approach is extended, evaluating the levelized cost of energy (LCOE) with a discounted cash-flow model. The LCOE are subsequently used to assess the effect on the economic potential by restricting the technical potential to an economically recoverable subvolume. Technical scenarios for 2020 , 2030, and 2050 time lines were used to estimate the different techno-economic scenarios for future EGS in 2020, 2030, and 2050. The resource assessment approach, the cash-flow model with the underlying assumptions for the different future scenarios, and the results for the economic potential are presented in Sect. 3 .

The results of this approach do not only delineate prospective areas for future EGS in Europe, but also show an economically constrained depth-dependent distribution of the technical potential. Finally, implications of the results and potential improvements are discussed.

\section{Temperature model}

\subsection{Methodology, model geometry and property distribution}

This model mainly relies on temperature and heat flow values measured at Earth's surface and on a simple distribution of thermal properties in the upper crust. The modeling routine is designed in a way that it can easily be extended with additional information such as local temperature models.

The model assumptions of the temperature model in this study are similar to the protocol proposed by Beardsmore et al. (2010), but a 3-D finite difference method is used to solve the boundary value problem and to generate a steadystate solution for the temperature. The methodology of the protocol was based on earlier work of Tester (2006) and has been used to assess the geothermal potential of the USA (Blackwell et al., 2007). When data are scarcely available it is a fast way to generate an adequate temperature model for a large area such as Europe or the USA. It makes optimal use of data that are relatively easy to acquire and the variability of the model parameters can be easily adjusted whenever more data have become available. For this method, considering the European scale of the application, local convection is neglected and it is assumed that heat is transported via thermal conduction.

The model works on a voxet (a regular 3-D grid representation), which for the European assessment was chosen at a resolution of 10 by $10 \mathrm{~km}$ in northing and easting and by $0.25 \mathrm{~km}$ in depth. Depending on the location, each vertical column of stacked grid cells can represent two layers: one layer that represents sedimentary cover and the other layer that represents the crustal basement (Fig. 1, Table 1). Both 
Table 1. Model geometry and boundary conditions.

\begin{tabular}{lll}
\hline Model & & Reference \\
\hline Topography & ETOPO1 & Amante and Eakins (2009) \\
$\begin{array}{l}\text { Basement depth and } \\
\text { crustal thickness }\end{array}$ & EuCRUST-07; CRUST2.0 & Tesauro et al. (2008); Bassin et al. (2000) \\
$\begin{array}{lll}\text { Surface temperature } \\
\text { Surface heat flow }\end{array}$ & WorldClim & Hijmans et al. (2005) \\
\hline
\end{tabular}

\section{Geometry and properties Boundary conditions}

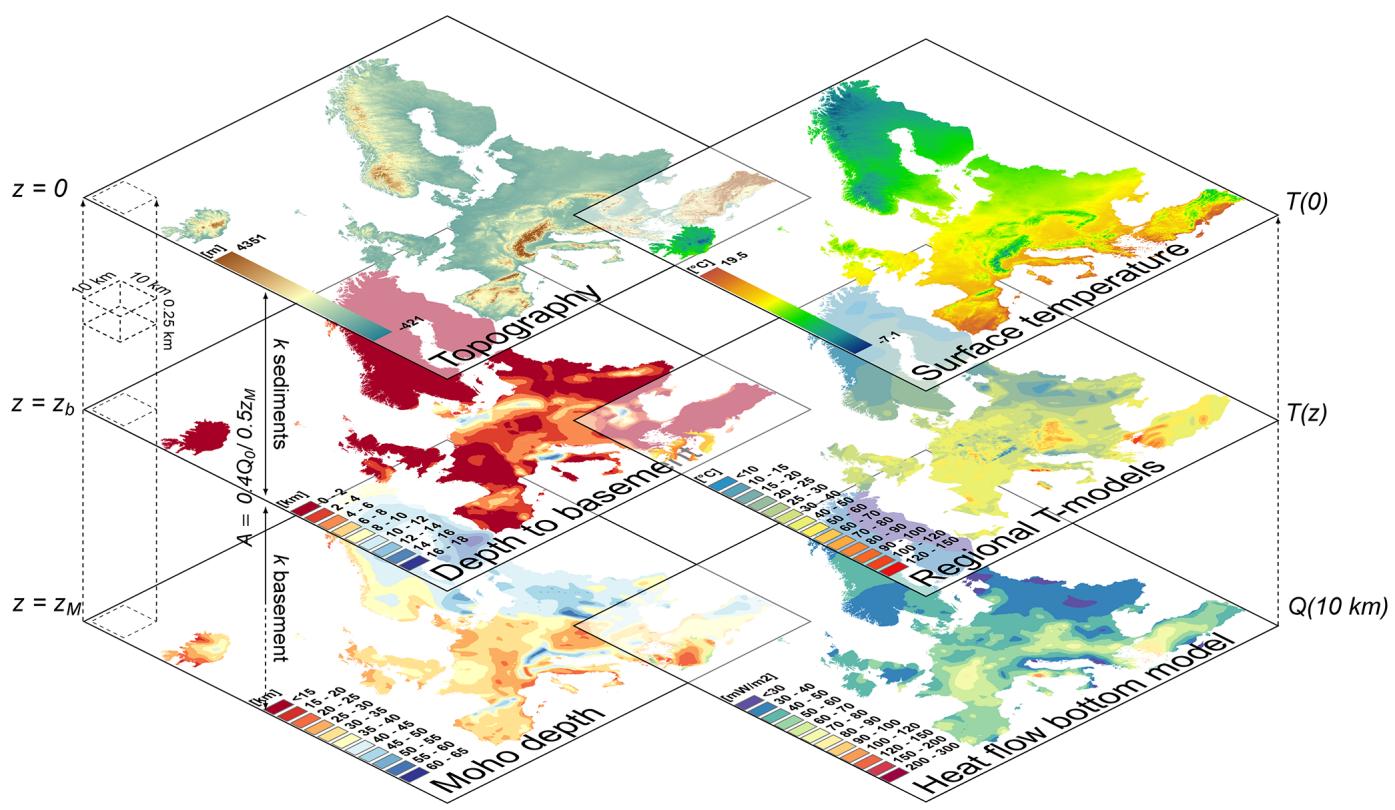

Figure 1. In this model a two-layer setup is used to assign values for $k$. For each $x y$ column, values of radiogenic heat production $A$ were calculated and assigned assuming that $40 \%$ of the surface heat flow $Q_{0}$ has been generated by radiogenic heat production in the crust (Eq. 1). Following the same assumption, the heat flow at the base of the model at $10 \mathrm{~km}$ depth was calculated (Eq. 2). As boundary conditions for the top and bottom of the model, annual surface temperatures and heat flow at $10 \mathrm{~km}$ depth were used, respectively. Along the vertical edges of the model zero heat flow was assumed. Temperatures from regional temperature models are set as fixed values in the corresponding grid cells (Table 2).

layers have two thermal properties: thermal conductivity $(k)$ and radiogenic heat production $(A)$.

Values for $k$ are assigned according to the vertical position relative to the boundary between the sedimentary cover and the crustal basement. This boundary represents the depth of the sediment-basement interface $(S)$ that divides the two layers.

The sediment thickness or the depth of $S$ is created by using the sediment thickness map from the high-resolution $\left(0.25^{\circ}\right.$ by $\left.0.25^{\circ}\right)$ EuCRUST-07 model from Tesauro et al. (2008). This model is a compilation of existing sediment thickness maps that, where possible, have been improved by using seismic profiles. Because the EuCRUST-07 model does not fully cover the area of interest (eastern Turkey and eastern Ukraine are missing) the CRUST 2.0 model from Bassin et al. (2000) (with the sediment maps from Laske and Mas- ters, 1997) is used. This model is largely based on the sediment thickness from the Tectonic Map of the World, created by Exxon Production Research Company (1995).

For the sediments, an average value for $k$ of $2.0 \mathrm{~W} \mathrm{~m}^{-1} \mathrm{~K}^{-1}$ was used, based on basin modeling predictions for lithologies which have not been subject to metamorphism (e.g., Hantschel and Kauerauf, 2009; Van Wees et al., 2009). For the European crystalline basement, dominated by plutonic and metamorphic rocks, a value of $2.6 \mathrm{~W} \mathrm{~m}^{-1} \mathrm{~K}^{-1}$ was adopted (e.g., Hantschel and Kauerauf, 2009; Van Wees et al., 2009).

To obtain values for $A$ in each grid cell the partition model of Pollack and Chapman (1977) was applied. Using the sur- 
face heat flow $Q_{0}$ and depth $Z_{M}$ of the Moho, $A$ was calculated for every grid cell by

$A_{z}=\frac{0.4 Q_{0}}{0.5 z_{M}}$

which forces $A_{z}\left(\mathrm{~W} \mathrm{~m}^{-3}\right)$ to be constant with depth, but to vary laterally according to $Q_{0}\left(\mathrm{~W} \mathrm{~m}^{-2}\right)$ and $z_{M}(\mathrm{~m})$. It was assumed that the upper crust forms half of the thickness of the total crust, which is approximately half of the depth of the Moho. The Moho depth in Europe varies from 15 to $63 \mathrm{~km}$ and was also derived from the EuCRUST-07 model from Tesauro et al. (2008) and is complemented by the CRUST 2.0 model from Bassin et al. (2000) to cover eastern Turkey and parts of Ukraine.

In nature, radiogenic heat production can show variations of up to several orders of magnitude even in samples that have been taken within a $1 \mathrm{~km}$ distance from each other (Vilà et al., 2010). A constant heat production with depth may not be realistic, but the advantage of the adopted model is that it reduces $A$ to a simple function of $Q_{0}$, which is capable of capturing the most important cause for regional heat flow variations, as reflected by correlation of regional variations of the surface heat flow $Q_{0}$ and the average radiogenic heat production observed in upper parts of the crust (Hasterok and Chapman, 2011).

The model works generally well in stable cratonic areas but, in more tectonically active regions, heat flow measurements can be severely affected by transient effects (Artemieva, 2011).

\subsubsection{Boundary conditions}

For the top of the model, constant values for the surface temperature $\left(T_{0}\right)$, of the WorldClim Global Climate Database from Hijmans et al. (2005), are imposed as a Dirichlet boundary condition. This data set contains mean temperatures from 24542 locations that represent the 1950-2000 time period. As reference level for the top, the ETOPO1 1 arc-minute Global Relief Model of Amante and Eakins (2009) is used.

As a Neumann boundary condition for the base of the model at $10 \mathrm{~km}$ below ground level, constant heat flow values are imposed. The heat flow at $10 \mathrm{~km}\left(Q_{10 \mathrm{~km}}\right)$ is obtained by subtracting the sum of the total radiogenic heat production of a column of stacked grid cells from the surface heat flow (Eq. 2).

$Q_{10 \mathrm{~km}}=Q_{0}-\sum_{z=0}^{z=10 \mathrm{~km}} A_{z}$

For the surface heat flow $\left(Q_{0}\right)$, the heat flow model of Europe from Cloetingh et al. (2010) is used, except for Iceland where the geothermal atlas was used (Hurter and Haenel, 2002).

At the vertical edges of the model, values of zero heat flow are imposed, which can be considered as a special case of a
Table 2. Input depth slices of subsurface temperature models (b.g.l. - below ground level)

\begin{tabular}{lll}
\hline Area & Depth $(\mathrm{km}$ b.g.l.) & Reference \\
\hline France & $1,2,3,4,5$ & Bonté et al. (2010) \\
Germany & $1,2,3,4,5$ & Agemar et al. (2012) \\
Ireland & 1,5 & Goodman et al. (2004) \\
The Netherlands & $1,2,3,4,5,6$ & Bonté et al. (2012) \\
United Kingdom & 1 & Busby et al. (2011) \\
Europe & 1,2 & Hurter and Haenel (2002) \\
\hline
\end{tabular}

Neumann boundary condition. Finally, this model calculates temperature values in the 3-D grid, given the 3-D thermal conductivity and radiogenic heat production structure.

\subsubsection{Input temperature models}

Subsurface temperature models were collected from several geologic surveys, including France, Germany, Ireland, the UK and the Netherlands (Table 2). Apart from the UK, which only provided a map of $1 \mathrm{~km}$ depth, the subsurface temperature models provide constraints of up to a depth of $5 \mathrm{~km}$. All of these models are based on bottom-hole temperature (BHT) or drill-stem test (DST) data, but their methodologies to compute them differ.

The French model from Bonté et al. (2010) and the German model from Agemar et al. (2012) are based on 3-D kriging geostatistical estimation. The Irish model from Goodman et al. (2004) is based on 2-D natural neighbor interpolation and the deeper temperature intervals have been generated by simple extrapolation of the average geothermal gradients observed in the boreholes. The UK model from Busby et al. (2011) is based on a 2-D interpolation of BHT data using a minimum curvature algorithm.

The Dutch temperature model from Bonté et al. (2012) uses the most comprehensive approach based on a three-step Runge-Kutta finite difference approach with a finite volume approximation. This model approach incorporates the effects of petrophysical parameters, including thermal conductivity and radiogenic heat production, as well as transient effects that affect temperature. Examples of transient effects are the accumulation of sediments, erosion and crustal deformation.

To use as much reliable temperature data as possible, we merged the regional temperature models and incorporated them in the modeling routine. To have constraints for the areas where no temperature models were available, the digitized subsurface temperature maps of 1 and $2 \mathrm{~km}$ depths from the geothermal atlas of Hurter and Haenel (2002) were also included.

For areas where more than one temperature value was available, we preferred to use values from integrated models over values derived by interpolation. For regional models where a similar methodology was used, we looked at the amount of measurements that were incorporated near the 

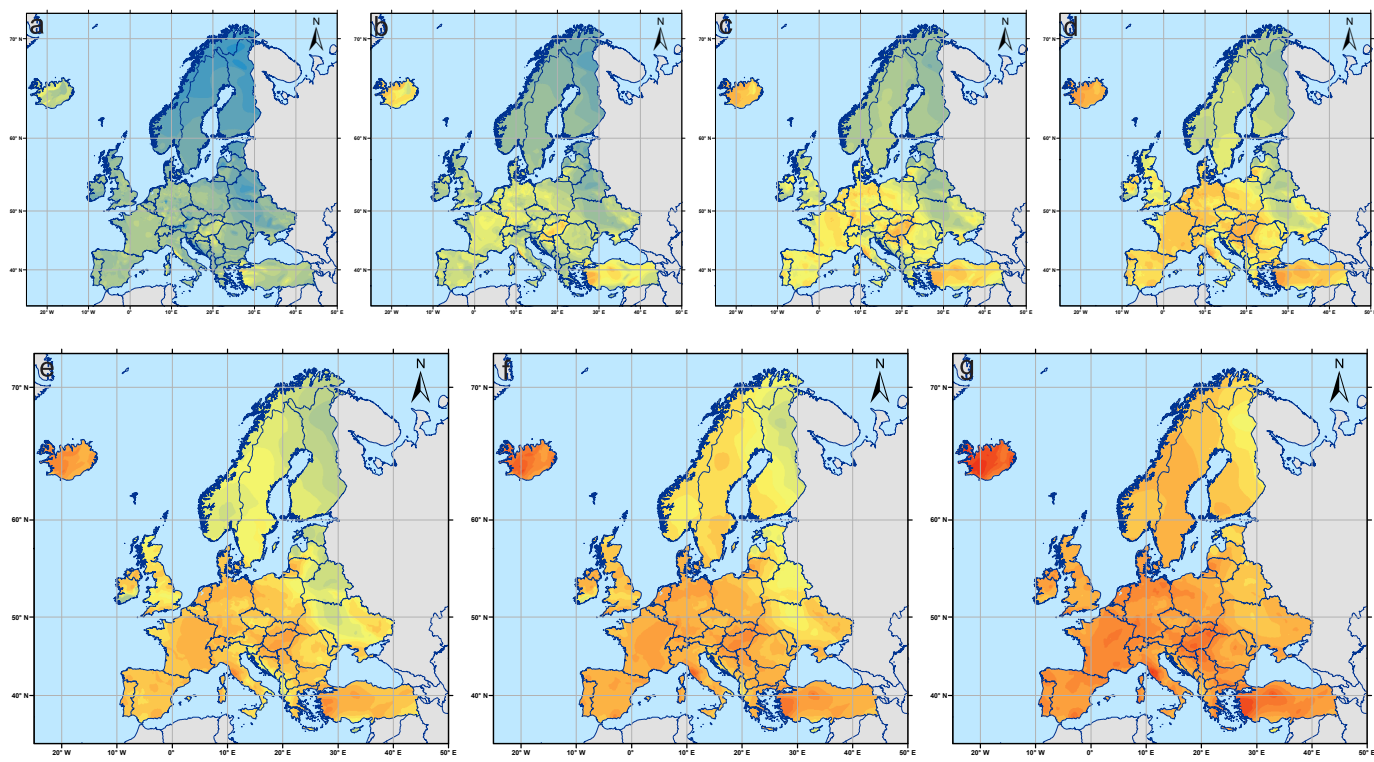

Temperature $\left[{ }^{\circ} \mathrm{C}\right]$

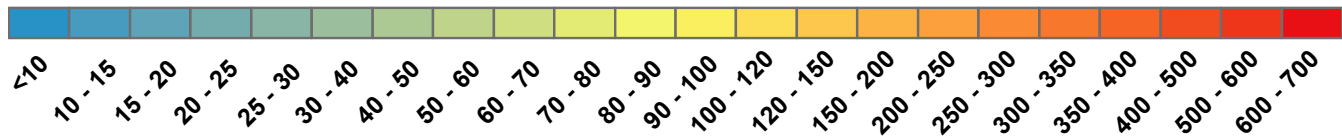

Figure 2. Depth slices of the modeled temperature voxet. Depths are below ground level. (a) $1 \mathrm{~km}$, (b) $2 \mathrm{~km}$, (c) $3 \mathrm{~km}$, (d) $4 \mathrm{~km}$, (e) $5 \mathrm{~km}$, (f) $7 \mathrm{~km}$ and (g) $10 \mathrm{~km}$.

shared boundary. We have chosen the Dutch model for the overlapping areas between the Dutch and German models and the German model for the overlapping areas between France and Germany.

Next, we replaced the calculated temperature values with the values from the merged temperature models without any smoothing. This approach could potentially cause discrepancies along shared borders between countries, as well as inconsistencies between the imported temperatures and the calculated heat flow. However, it enables the inclusion of more reliable data based on temperature measurements.

\subsection{Modeling results}

The outcome of the temperature modeling routine is a 3-D temperature voxet which contains values for every 10 by 10 by $0.25 \mathrm{~km}$ cell. Depth slices of the model taken at shallow to intermediate depth levels of $1-10 \mathrm{~km}$ are shown in Fig. 2.

The model shows high average geothermal gradients of up to $60^{\circ} \mathrm{C}$ in volcanically active regions such as Iceland, parts of Italy, Greece and Turkey. Especially in Iceland and around volcanic regions in Italy, temperatures can reach more than $300^{\circ} \mathrm{C}$ at a depth of $5 \mathrm{~km}$ and more than $500^{\circ} \mathrm{C}$ at a depth of $10 \mathrm{~km}$. What really stands out, apart from the regions with elevated temperatures, is the profound division between relatively high temperatures in the southwestern part of Europe and low temperatures in the northeastern part. These colder zones are mostly constrained to the East European Craton and to the Fennoscandian or Baltic Shield.

This dichotomy fits with the Trans-European Suture Zone (TESZ), which marks a clear division between the stable Precambrian Europe and the dynamic Phanerozoic Europe (Pharaoh, 1999; Jones et al., 2010; Artemieva, 2011). The Precambrian zone has large lithosphere thicknesses and the Moho lies deeper, while in the Phanerozoic part of Europe the lithosphere is thinner and the Moho lies more shallow (Tesauro et al., 2008).

At $5 \mathrm{~km}$ depth (Fig. 2e) the model has a mean temperature of $111^{\circ} \mathrm{C}$ and a total range varying between 40 and $310^{\circ} \mathrm{C}$ and a standard deviation $\sigma$ of 44 . At $10 \mathrm{~km}$ depth (Fig. $2 \mathrm{~g}$ ) the mean temperature is $201^{\circ} \mathrm{C}$, a total range between 80 and $590^{\circ} \mathrm{C}$ and $\sigma=74$.

The lowest temperatures at $10 \mathrm{~km}$ depth are around $80^{\circ} \mathrm{C}$, which is in line with geothermal gradients of $5-10^{\circ} \mathrm{C} \mathrm{km}^{-1}$ that are observed in old cratonic crust (Artemieva, 2011). In the model, large anomalies between the observed and modeled temperature could be an indication for the presence of thermal convection (Bonté et al., 2012). These temperature anomalies can be used as a proxy for high permeability as was shown for the Netherlands by Van Oversteeg et al. (2014). 


\section{Techno-economic model}

\subsection{Methodology}

To develop a geothermal system it is necessary to have favorable geological conditions, including a high temperature and appropriate reservoir properties. However, favorable geological conditions alone are not enough to initiate any commercial development. Because the development of a geothermal system involves high upfront costs and high financial risks (mostly related to drilling), it is vital to assess the financial feasibility for different scenarios. For the GeoElec project we applied a methodology that incorporates economic parameters in the estimation of geothermal resources in Europe. The main outputs from this method are the minimum LCOE and the economic power potential. Both are calculated on the basis of the temperature model described earlier. Because it is difficult to constrain the flow rate without information from a well, fixed flow rates have been used for the calculations, building from the generalized assumption that natural permeability can be enhanced - through stimulation - to sustain the assumed flow rates.

The techno-economic model uses the 3-D temperature voxet derived from the temperature modeling routine as input for its calculations. The complexity of this technoeconomic model lies in the large quantity of variables inherent to economic problems, rather than in the mathematical solution. The model is based on a combination of the volumetric approach of Beardsmore et al. (2010) and a discounted cash-flow model from Lako et al. (2011) and Van Wees et al. (2012). The model is digitally available as an Excel spreadsheet. As depicted schematically in Fig. 3, the temperature model voxet is used to generate voxets for the heat in place $H(\mathrm{~J})$, the theoretical potential $P_{\text {theory }}$ $\left(\mathrm{MW}_{\mathrm{e}}\right)$, the technical potential $P_{\text {technical }}\left(\mathrm{MW}_{\mathrm{e}}\right)$ and finally the LCOE $\left(E_{\text {EUR MWh }}^{-1}\right)$. The LCOE values are used to restrict $P_{\text {technical }}$ to obtain the economic potential $P_{\text {economic }}$ $\left(\mathrm{MW}_{\mathrm{e}}\right)$. It is important to keep in mind that this methodology is based on a number of assumptions and that these potentials provide only an indication of the global European prospective resource base. In these following subsections the main concepts and assumptions used in this methodology are described.

\subsubsection{Heat in place}

Following the protocol of Beardsmore et al. (2010), the theoretically available thermal energy or heat in place $H(\mathrm{~J})$ is calculated by combining Eq. (3a) with Eq. (3b):

$H=V_{\text {rock }} \times \rho_{\text {rock }} \times C p_{\text {rock }}\left(T_{z}-T_{r}\right)$,

$T_{r}=T_{0}+T_{i}$.

Where $V_{\text {rock }}$ is the volume of the rock $\left(\mathrm{m}^{3}\right), \rho_{\text {rock }}$ is the density of the rock $\left(\mathrm{kg} \mathrm{m}^{-3}\right)$ and $C p_{\text {rock }}$ is the heat capacity of the rock $\left(\mathrm{J} \mathrm{kg}^{-1} \mathrm{~K}^{-1}\right)$. The temperature difference that is

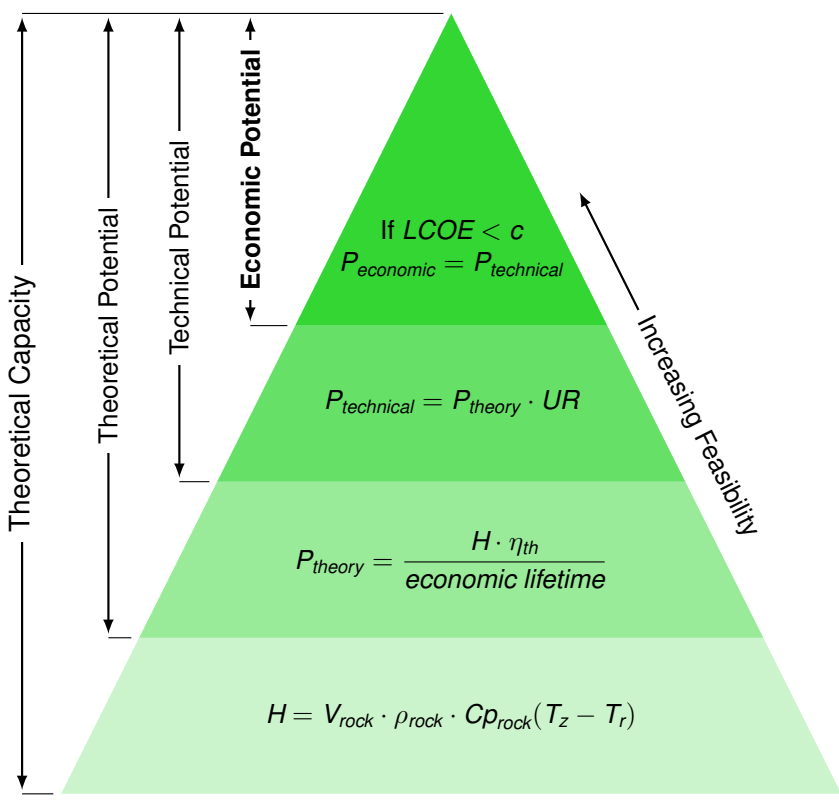

Figure 3. Assessment of the potential power output from a geothermal system. The theoretical capacity is the amount of thermal energy physically present in the reservoir rocks of a certain area or prospect. The theoretical potential describes the total amount of power that can be converted from the theoretical capacity within a certain period of time using a conversion efficiency. The technical potential is that part of the theoretical potential that can be exploited with current technology available calculated using a recovery factor. The economic potential describes the part of the technical potential that can be commercially exploited for a range of economic conditions. In this study we used different cutoff values for the LCOE (c) so the total costs of the system would fall in the same range as existing geothermal energy systems or other competing forms of energy production.

available for geothermal power is assumed to be the difference between $T_{z}\left({ }^{\circ} \mathrm{C}\right)$ (the temperature at depth $z$ ) and the base or reinjection temperature $T_{\mathrm{r}}\left({ }^{\circ} \mathrm{C}\right) . T_{\mathrm{r}}$ is the temperature to which the reservoir can theoretically be cooled using a surface temperature and $T_{i}$. For $T_{i}$ we assumed a default value of $80^{\circ} \mathrm{C}$ (Williams et al., 2008).

\subsubsection{Theoretical potential and efficiency}

Next, $H$ is converted into the theoretical potential $P_{\text {theory }}$ $\left(\mathrm{W}_{\mathrm{e}}\right)$ which is the power that could be theoretically produced during the expected lifetime of the system. $P_{\text {theory }}$ marks the upper limit of the theoretically realizable power output and is calculated from $H$ by combining Eq. (4a) with Eq. (4b):

$$
\begin{aligned}
& P_{\text {theory }}=\frac{H \times \eta_{\mathrm{th}}}{t}, \\
& \eta_{\text {th }} \approx \frac{T_{z}-T_{0}}{T_{z}+T_{0}} \times \eta_{\text {relative }} .
\end{aligned}
$$


Table 3. Important assumptions on economic parameters and the main results, including LCOE, theoretical potential, economic potential and the effective ultimate recovery.

\begin{tabular}{lllll}
\hline Parameter/result & Unit & 2020 & 2030 & 2050 \\
\hline Maximum depth & $\mathrm{m}$ & 7000 & 7000 & 10000 \\
Flow rate & $\mathrm{L} \mathrm{s}^{-1}$ & 75 & 100 & 100 \\
COP & $\mathrm{MW}_{\text {th }} \mathrm{MW}_{\mathrm{e}}{ }^{-1}$ & 30 & 50 & 1000 \\
Well cost model: & - & - & ThermoGIS (1.5) & EUR $1500 \mathrm{~m}^{-1}$ \\
$\quad<5200 \mathrm{~m}$ & - & ThermoGIS (1.5) & - & - \\
$>5200 \mathrm{~m}$ & - & WellCost Lite (1.0) & - & - \\
Stimulation costs & $\mathrm{M} \mathrm{EUR} \mathrm{per} \mathrm{well}$ & 10 & 10 & 10 \\
$\eta_{\text {relative }}$ & - & 0.6 & 0.6 & 0.7 \\
$T_{i}$ for $T_{r}$ & ${ }^{\circ} \mathrm{C}$ & 80 & 80 & 50 \\
LCOE cutoff $(c)$ & $\mathrm{EUR} \mathrm{MWh}^{-1}$ & 200 & 150 & 100 \\
\hline LCOE Base case & $\mathrm{EUR} \mathrm{MWh}^{-1}$ & 215 & 127 & 70 \\
Theoretical potential & $\mathrm{TW}_{\mathrm{e}}$ & 14 & 14 & 22 \\
Economic potential & $\mathrm{GW}_{\mathrm{e}}$ & 19 & 22 & 522 \\
Effective UR & $\%$ & 0.1 & 0.2 & 2.4 \\
\hline
\end{tabular}

$\eta_{\text {th }}$ describes the estimated thermal efficiency of the power plant and $t$ the expected lifetime of the geothermal system. The efficiency $\eta_{\text {th }}$ is also known as the cycle thermal efficiency of a power plant and is the efficiency at which the heat energy is converted to electrical energy, from Eq. (4b) it follows that high $\eta_{\text {th }}$ values are realized when there is a large difference between the inlet temperature, assumed to be equal to the temperature at depth $T_{z}$, and the outlet temperature, assumed to be equal to the surface temperature $T_{0}$. Typical values for $\eta_{\text {th }}$ range between 0.1 and 0.2. (DiPippo, 2007; Clauser, 2011).

To calculate $\eta_{\text {th }}$ we made use of $\eta_{\text {relative }}$ to convert from the ideal to the practical $\eta_{\mathrm{th}}$. DiPippo (2007) documented values of $\eta_{\text {relative }}$ ranging from 0.44 to 0.85 with an average of 0.58 . We have chosen similar values based on observed relative efficiencies for low to medium enthalpy binary systems (Table 3).

\subsubsection{Technical potential}

The technical potential $P_{\text {technical }}\left(\mathrm{W}_{\mathrm{e}}\right)$ is the fraction of $P_{\text {theory }}$ that can be theoretically produced, within the limits of current technology. In this case, the broadest definition for technical limits is used and includes geological limitations and technical limitations, such as drilling and power plant technology, but also environmental and political limitations. For example, some geothermal energy systems with promising geological potential cannot be developed because they are located in nature reserves, densely populated areas or areas where (sub)surface exploitation has been (temporarily) prohibited for political or legal reasons. Consequently, some areas can have a limited $P_{\text {technical }}$ permanently, while for other areas limits on $P_{\text {technical }}$ can be temporary.

Because it is difficult to precisely quantify all the different types of limitations, $P_{\text {technical }}$ is often derived by multiplying
$P_{\text {theory }}$ with an ultimate recoverability factor UR (Eq. 5a).

$P_{\text {technical }}=P_{\text {theory }} \times \mathrm{UR}$

$\mathrm{UR}=R_{\mathrm{av}} \cdot R_{f} \times R_{\mathrm{TD}}$

Equation (5b) describes how UR can be determined by combining the recovery factors corresponding to limitations in available land area $\left(R_{\mathrm{av}}\right)$, limitations in the recovery of heat from a fracture network $\left(R_{\mathrm{f}}\right)$ and limitations caused by the effect of temperature drawdown $\left(R_{\mathrm{TD}}\right)$. Beardsmore et al. (2010) recommended using a value between 1 and $20 \%$ for UR, based on the work of Tester (2006) and Williams et al. (2008). This range of values for UR is based on the average recovery factor for all the layers with temperatures exceeding the base temperature within the total rock column beneath a selected area. For the volumetric estimation of the resource base, no distinction is made between (known) good reservoir rocks (e.g., coarse sandstones or karstified carbonates) and poor reservoir rocks (e.g., tight shales or low-permeability igneous rocks). For actual geothermal reservoirs, values for UR can be much higher and typically vary between 10 and $50 \%$ (Dumas et al., 2013). We decided to omit $R_{\mathrm{av}}$ at the scale of each individual grid cell, but for the European-scale assessment, the total land area available in each country was limited to $25 \%\left(R_{\mathrm{av}}=0.25\right)$. For $R_{\mathrm{f}}$, the lower bound value of 0.14 proposed by the protocol of Beardsmore et al. (2010) was used and for $R_{\mathrm{TD}}$ fraction we assumed a value of 0.9 . This results in an UR of ca. $12.5 \%(0.14 \times 0.9)$ for each individual grid cell. Consequently, for calculating the potential of each country, the UR of a grid cell is limited to ca. $3 \%$ $(0.25 \times 0.14 \times 0.9)$. 


\subsection{Levelized cost of energy}

For potential investors it is essential to quantify the economic potential of a geothermal energy system. Any economic potential study should base its calculations on the investment costs, also known as capital expenditures (CAPEX), and the operational costs, known as operational expenditures (OPEX). Both are usually expressed in EUR cents or USD cents per kilowatt or megawatt of installed capacity.

CAPEX is the sum of all the initial capital, $I_{t}$, that needs to be invested in a geothermal energy project in the year $t . I_{t}$ includes the investment costs such as the exploration costs, the drilling costs for the wells, the construction costs of the power plant including grid connection, the costs of reservoir stimulation and the costs of financing and commissioning the whole system. OPEX is the sum of all the operational and maintenance expenses, $M_{t}$, that are made in the year $t . M_{t}$ includes costs of personnel and equipment, costs of maintenance and, if required, costs of re-stimulation of the reservoir or the drilling of replacement wells. Tax $t$ is the amount of tax that is paid in the year $t, E_{t}$ is the amount of electricity produced in the year $t$, and $r$ is the discount rate or inflation.

$E_{t}=Q \times \rho_{\text {water }} \times C p_{\text {water }}\left(T_{z}-T_{r}\right) \times \eta_{\text {th }} \times 10^{-3} \times t_{\text {load }}$

Following Eq. (6), $E_{t}$ is calculated with flow rate $Q\left(\mathrm{~L} \mathrm{~s}^{-1}\right)$, water density $\rho_{\text {water }}\left(\mathrm{kg} \mathrm{m}^{-3}\right)$ and the heat capacity of water $C p_{\text {water }}\left(\mathrm{J} \mathrm{kg}^{-1} \mathrm{~K}^{-1}\right) . \eta_{\text {th }}$ is used to convert from thermal power to electrical power and $t_{\text {load }}$ is the time (hours per year) at which the plant is fully operational. $E_{t}$ will only be calculated for grid cells for which the temperature is sufficiently high $\left(T_{z}>T_{r}\right)$.

Once $I_{t}, M_{t}$ and $E_{t}$ are calculated and discounted using $r$, it is possible to calculate the expected costs per unit power or LCOE (Van Wees et al., 2012). The LCOE is calculated using Eq. (7):

LCOE

$=\frac{\text { cumulative discounted yearly net revenue }}{\text { cumulative discounted yearly electricity production }}$

$=\frac{\sum_{t=1}^{T} \frac{I_{t}+M_{t}+\operatorname{Tax}_{t}}{(1+r)^{t}}}{\sum_{t=1}^{T} \frac{E_{t}}{(1+r)^{t}}}$.

Here the total discounted expenditures made during the project's lifetime in EUR are divided by the total discounted energy produced in megawatt hours for an expected lifetime $T$ in years. The total discounted life cycle costs are equal the sum of all the discounted CAPEX, OPEX, and taxes from year $t=1$ to $t=T$. The total lifetime energy production is the sum of the discounted energy produced from year $t=1$ to $t=T$. The discount is imposed by dividing the sum of the CAPEX and OPEX in year $t$ and the energy production in year $t$ by $(1+r)^{t}$. LCOE can only be calculated for grid cells where $E_{t}>0$.

The outcome of this calculation are the levelized costs per unit of energy produced over time in EUR cents per kilo- watt hour or EUR per megawatt hour, which represent the costs that an energy provider would need to charge to break even. The LCOE for future EGS were calculated for technoeconomic scenarios in 2020, 2030, and 2050 for which the full list of input parameters and default values can be found in Appendix A. Changes to the default values for the specific scenarios can be found in Table 3 .

The LCOE is an economic parameter that is commonly used to describe the costs of energy for conventional and emerging power producing technologies, and provides an easy way to compare the costs between different energy systems. However caution must be taken when comparing the LCOE between sources of power that are dispatchable or nondispatchable. Enhanced geothermal systems that use pumps to produce geothermal fluids can be considered dispatchable since the power output can be adjusted by varying the pumping pressure. Power sources that are nondispatchable cannot simply adjust the power output on demand because they are dependent on energy sources that are strongly variable, such as the wind or the sun.

Besides dispatchability, an important factor for replacing conventional power plants with an alternative form is the capacity factor $\mathrm{CF}$. CF is the ratio of the actual energy output and the maximum energy output that a power plant could produce when always operating at full capacity. The actual energy output is always lower than the maximum energy output since a power plant can be out of service or operating at a lower capacity due to equipment maintenance or failure or, in the case of solar or wind power, due to lack of resources. According to Goldstein et al. (2011), the average $\mathrm{CF}$ of all operational geothermal power plants is $74.5 \%$, while new plants often reach $90 \%$ or more. This is higher than the $\mathrm{CF}$ of coal- and gas-fired power plants and much higher than the $\mathrm{CF}$ of other renewable energy technologies that are dependent on weather, such as solar and wind power (Goldstein et al., 2011; U.S. Energy Information Administration, 2012; REN21, 2014). Conventional geothermal energy systems have proven to be generally reliable and are able to provide base-load electricity. Because EGS systems work on the same principles as conventional geothermal systems, it is assumed that the $\mathrm{CF}$ will be in the same range as for conventional systems. For this study we assumed $t_{\text {load }}=8000 \mathrm{~h}$, corresponding to $\mathrm{CF} \approx 91 \%$.

\subsubsection{Well cost models}

To estimate the economic potential we combine the volumetric resource assessment with the techno-economic model described earlier in Sect. 3.2. A great portion of the CAPEX is determined by the costs that are related to the drilling of the wells. Three different well cost models were used to calculate the investment costs (EUR per well): 


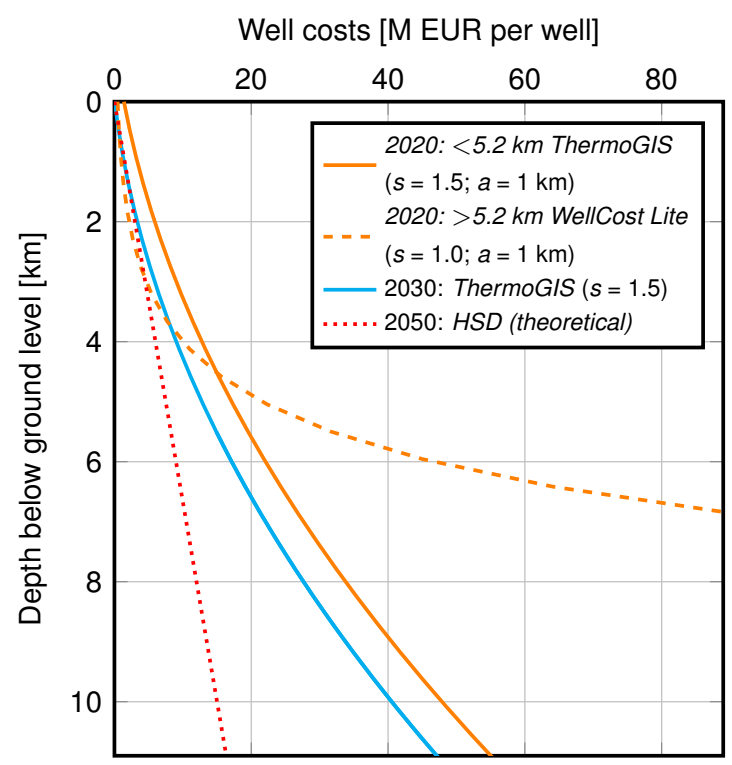

Figure 4. Well costs in million EUR for 2020, 2030, and 2050. (Eq. 8). For the 2020 scenario a combination of two well cost models is used. Above $5200 \mathrm{~m}$ the ThermoGIS model from Kramers et al. (2012) is applied, while below $5200 \mathrm{~m}$ the WellCost Lite model from Tester (2006) is used. For the 2020 scenario an additional $1000 \mathrm{~m}$ horizontal along hole length $a$ was added to replicate the divergent well layout normally used for an EGS doublet. For the 2030 scenario the same ThermoGIS model is used with $a=0$. For 2050 it is assumed that HSD is possible and well costs increase linearly with depth.

WellCost Lite $=s \times 10^{-0.67+0.000334(z+a)} \times n$,

ThermoGIS $=s \times\left(0.2(z+a)^{2}+700(z+a)+25000\right)$

$\times n \times 10^{-6}$,

$\mathrm{HSD}=1500 \times z \times n \times 10^{-6}$.

Where $s$ is the well cost scaling factor, $z$ is the depth (m), $a$ the possible extra horizontal length of the well (m) and $n$ the number of wells (see also Table 3 ).

The WellCost Lite model has been proposed by Tester (2006) and has been derived from historical records between 1976 and 2004 of well costs in the United States. The well costs in this model increase exponentially with depth, reflecting the increase in time and cost required for bit replacement at greater depths. The ThermoGIS well cost model is developed by TNO for the ThermoGIS project and is based on historical well costs in the Netherlands (Kramers et al., 2012).

For 2020, the WellCost Lite model and the ThermoGIS model were combined with $a=1000 \mathrm{~m}$. Up to a depth of $5200 \mathrm{~m}$, the ThermoGIS model is used with $s=1.5$, while below $5200 \mathrm{~m}$ the more exponential WellCost Lite model uses $s=1$. For 2030, only the ThermoGIS model is used with $s=1.5$ and $a=0$. For 2050 a linear well cost model is applied, based on the prediction that new drilling techniques such as hydrothermal spallation drilling (HSD) or plasma drilling will emerge (Augustine, 2009). Compared to exponential well cost models, the assumed drilling costs for HSD of EUR $1500 \mathrm{~m}^{-1}$ could especially lower the LCOE at greater depths (Fig. 4). Additionally, the higher temperatures that are expected at greater depths should increase the thermal efficiency $\eta_{\text {th }}$, which will also lower the LCOE.

Another advantage of geothermal energy is that the OPEX are relatively low and do not depend on fuel costs, contrary to the OPEX of conventional power plants, which can vary strongly due to the erratic development of coal and gas prices. The problems encountered with the development of geothermal energy systems are mostly related to the high upfront costs and the related finances. The high upfront costs are usually caused by the costs involved with the drilling of the wells. The problems with financing geothermal projects relate to the substantial uncertainties in the performance of the wells. EGS technology is still in a research and development stage since only a handful of projects have been realized (Breede et al., 2013). More experience with EGS needs to be gained and solutions for potential problems need to be developed before costs of EGS are expected to decline.

\subsubsection{Sensitivity analysis of the LCOE for EGS and comparison with other LCOE estimates}

Because most EGS are relatively new and commercial exploitation has just started it is difficult to assess the LCOE (Breede et al., 2013). According to (Goldstein et al., 2011) most existing conventional geothermal systems have LCOE that vary between USD $31 \mathrm{MWh}^{-1}$ and USD $170 \mathrm{MWh}^{-1}$. In the work of (Huenges, 2010) the LCOE is estimated at EUR $260 \mathrm{MWh}^{-1}$ and EUR $340 \mathrm{MWh}^{-1}$ for two hypothetical EGS in Europe. LCOE calculated by Tester (2006) for potential EGS projects in the US, range between ca. USD $100 \mathrm{MWh}^{-1}$ and USD $1000 \mathrm{MWh}^{-1}$. However, for the same cases 20 years into the future, assuming mature and cheaper technology, the calculated LCOE could be much lower, ranging between USD $36 \mathrm{MWh}^{-1}$ and USD $92 \mathrm{MWh}^{-1}$ (Tester, 2006). (Augustine, 2011) estimates the range of costs for present-day deep EGS between USD $140 \mathrm{MWh}^{-1}$ and USD $310 \mathrm{MWh}^{-1}$, with a mean of USD $210 \mathrm{MWh}^{-1}$. For 2020 the LCOE are estimated to be between 89 and $93 \%$ of the present-day values.

These costs should enable EGS in the near future to become competitive with conventional power sources, such as coal and gas, currently priced at USD $65 \mathrm{MWh}^{-1}$ USD $95 \mathrm{MWh}^{-1}$ in the US and EUR $38 \mathrm{MWh}^{-1}$ EUR $100 \mathrm{MWh}^{-1}$ in Europe (U.S. Energy Information Administration, 2014; Kost et al., 2013).

To make a comparison we applied our techno-economic model on a hypothetical EGS project situated near the RhineGraben, with a reservoir depth at $5000 \mathrm{~m}$ and a default temperature of $200^{\circ} \mathrm{C}$. For this hypothetical case, combined with our assumptions for future scenarios (Table 3), the model calculates LCOE of EUR $215 \mathrm{MWh}^{-1}$ in 2020 , 


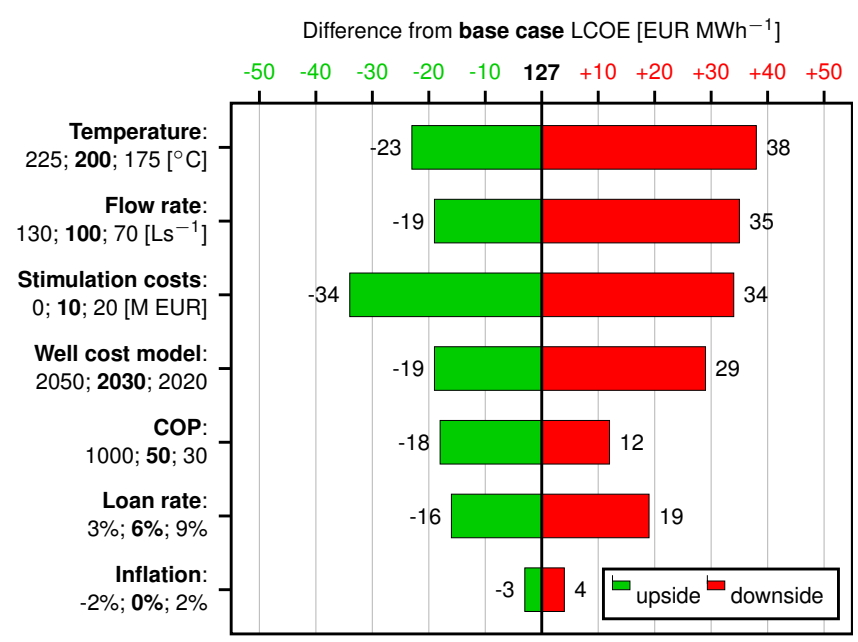

Figure 5. Tornado plot showing the sensitivity of the calculated LCOE to changes in a selection of parameters. The default settings of the 2030 scenario (bold) were applied to a reservoir at $5 \mathrm{~km}$ depth with a temperature of $200^{\circ} \mathrm{C}$ resulting in a LCOE of EUR $127 \mathrm{MWh}^{-1}$. For each of the selected parameters, we assumed values for what the upside and downside scenarios could be and calculated the effect on the LCOE compared to the base case.

EUR $127 \mathrm{MWh}^{-1}$ in 2030 and EUR $70 \mathrm{MWh}^{-1}$ in 2050 . The LCOE calculated for the 2020 scenario is in range with the estimates described earlier. The costs show a strong decline for the 2030 and 2050 scenarios and are comparable to the future scenarios from (Tester, 2006).

Figure 5 shows the sensitivity of the calculated LCOE to variations in a selection of parameters. For each of the selected parameters, we assumed values for what the upside and downside scenarios could be and calculated the difference compared to the LCOE for the 2030 scenario $\left(\right.$ EUR $127 \mathrm{MWh}^{-1}$ ). Temperature and flow rate have the largest uncertainty and variations in these parameters have a strong impact on the LCOE. Improving geothermal exploration is therefore essential to decrease the financial risks and to lower the LCOE. The effect on the LCOE of selecting different well cost models, together with variations in the stimulation costs and COP, reveal the importance of drilling technologies and stimulation techniques. The effect of drilling costs on the LCOE would have been even more profound for deeper reservoirs (Fig. 4). Lowering these costs is crucial for reaching higher temperatures at greater depths and increase the number of suitable locations for EGS, while enabling the installation of higher capacity power plants.

\subsection{Economic potential}

The economic potential describes the part of the technical potential that can be commercially exploited for a range of economic conditions. The total costs of the system should ideally fall within the same range as the costs for operational geothermal energy systems. The developable potential is the part of the economic potential that can actually be developed taking into account all economic and noneconomic circumstances (Rybach, 2010). It is usually smaller than the economic potential, but it can be larger if governments have policies to promote renewable energy, including geothermal energy, such as feed-in tariffs, favorable taxes and favorable risk insurances.

Important for utilizing EGS for periods longer than the initial life time, is the sustainable potential (Sanyal, 2005; Rybach, 2010). It describes the fraction of the economic potential that can be used with sustainable production levels, while taking into account the resource degradation over time caused by pressure drawdown or by declining reservoir temperatures (Sanyal, 2005). We did not account for this in our study, but the effect of reduced temperatures and flow rates on the LCOE is shown in Fig 5. The effect of stimulation costs on the LCOE in Fig. 5 can also be used to assess the effect of measures countering resource degradation (e.g., additional stimulation or drilling of new/relieve wells).

For this resource assessment, we restricted the technical potential to grid cells where the LCOE was lower than a given threshold $c$ (Eq. 9).

If $\mathrm{LCOE}<c: P_{\text {economic }}=P_{\text {technical }}$

For the 2020, 2030, and 2050 scenarios, values for $c$ of 200, 150 and 100 were chosen, respectively. These numbers were adopted to reflect the likely reduction of feed-in tariffs in the future beyond 2020 and renewable energy prices that will eventually become compatible with current fossil fuel-based energy prices (Tester, 2006; Goldstein et al., 2011).

To visualize the spatial distribution of the LCOE we compiled maps (Fig. 6) for each future scenario (Table 3), depicting the minimum value for the LCOE for each stacked $x y$ column of grid cells. Since fixed flow rates are assumed for the three different scenarios, the subsurface temperature automatically becomes the most important parameter. The LCOE distribution in the maps of 2020 and 2030 (Fig. 6a, b), therefore correspond largely to the areas where elevated temperatures are present at shallower depth. These mainly consist of volcanic areas such as Iceland, Italy and Turkey, but also sedimentary basins such as the Rhine-Graben, Pannonian Basin and the Southern Permian Basin. The LCOE map for the 2050 scenario clearly shows that the cost of drilling is a determining factor for the LCOE. Due to the use of a linear well cost model for the 2050 scenario, LCOE are lower than EUR $100 \mathrm{MWh}^{-1}$ for almost all of Europe southwest of the the TESZ.

To calculate the total economic potential for each stacked $x y$ column Eq. (10) was used:

$P_{\text {economic }}=\sum_{z=0}^{z=7-10 \mathrm{~km}}\left(P_{\text {economic }}\right)_{z}$.

For the country outlooks, the $P_{\text {economic }}$ for each country is summed and then multiplied by 0.25 to limit the economic 

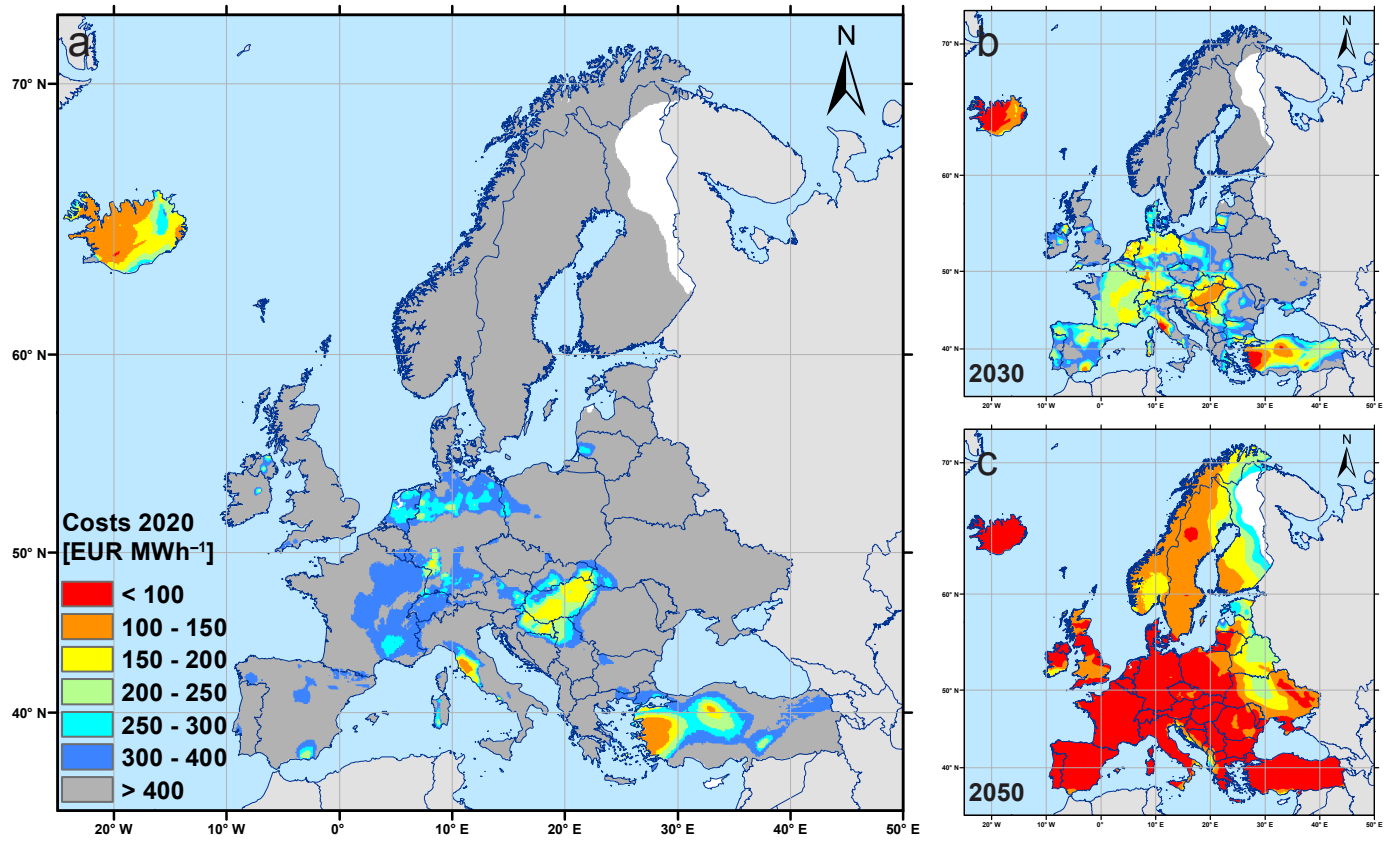

Figure 6. Maps depicting the calculated minimum levelized cost of energy (for each stacked $x y$ column) in (a) 2020 , (b) 2030 and (c) 2050.

potential for land use restrictions. For 2020 and 2030, only the potentials up to a depth of $7 \mathrm{~km}$ are considered, while for 2050 the maximum depth is extended to $10 \mathrm{~km}$. The economic potentials for 2020, 2030, and 2050 are 19, 22 , and $522 \mathrm{GW}_{\mathrm{e}}$, respectively.

The effect of the different values of the LCOE threshold $c$ is illustrated in Fig. 7, where the economic potentials are plotted for $c$ values varying between EUR $300 \mathrm{MWh}^{-1}$ and EUR $50 \mathrm{MWh}^{-1}$. The economic potentials for the whole area considered in this study can be found in Table 3 , along with the most important assumptions for each scenario.

By dividing $P_{\text {economic }}$ by $P_{\text {technical }}$, we calculated the effective UR. This results in an UR of $0.1 \%$ for $2020,0.2 \%$ for 2030 , and $2.4 \%$ for 2050 . The large difference of the $P_{\text {economic }}$ and UR of 2020 and 2030 compared to 2050, can mostly be ascribed to the use of a linear well cost model combined with the increase in the maximum drilling depth from 7 to $10 \mathrm{~km}$, enabling exploitation of deeper reservoirs with higher temperatures.

We also assumed that all wells will be self-flowing in 2050, by adopting a COP of 1000 (Table 3). From theoretical considerations, it can be argued that well pressures in production and injection wells can be self-flowing, provided the reservoir temperature is in excess of $220^{\circ} \mathrm{C}$ and the reservoir is located sufficiently deep (e.g., Sanyal et al., 2007). Due to the assumed lower drilling costs in 2050, it becomes financially feasible to drill for these deeper reservoirs with higher temperatures. Furthermore, by adopting a threshold value $c$ of EUR $100 \mathrm{MWh}^{-1}$ for 2050 , these higher temperatures and associated larger depths are also implicitly required.

\section{Discussion and conclusions}

The economic resource assessment clearly demonstrates the strong sensitivity of the spatial and depth distribution of economic potential to both subsurface and cost parameters. Temperature and flow rate are the most important constraints for the development of an EGS project. These parameters are also the most uncertain since their exact values can only be determined by drilling a well and successfully creating a reservoir. For the LCOE, costs of drilling is the most important parameter, and the models clearly demonstrate the significant impact in the economic potential through a lowered cost curve for the 2020, 2030, and 2050 scenarios.

To reduce the uncertainty for the temperature, the temperature model should be improved. For this work, a simple two-layer conductive model is used where values for $k$ are distributed according to their location in respect to the sediment-basement interface for the basement. This could be improved by adopting a higher resolution for the thermal properties $k$ and $A$, based on lithological information and well data (e.g., Clauser, 2011; Bonté et al., 2012).

The underlying cause for variations in radiogenic heat production in the upper crust are lithological variations (e.g., Hasterok and Chapman, 2011). Inclusion of lithological interpretations of crustal composition for thermal properties $(k$ and $A$ ) could strengthen the geological interpretation and robustness of the models. This has been considered beyond the scope of the present study as little detailed information is readily available on the crustal lithology at a European scale (Tesauro et al., 2008) and - in the adopted workflow - would most likely not affect first-order temperature vari- 

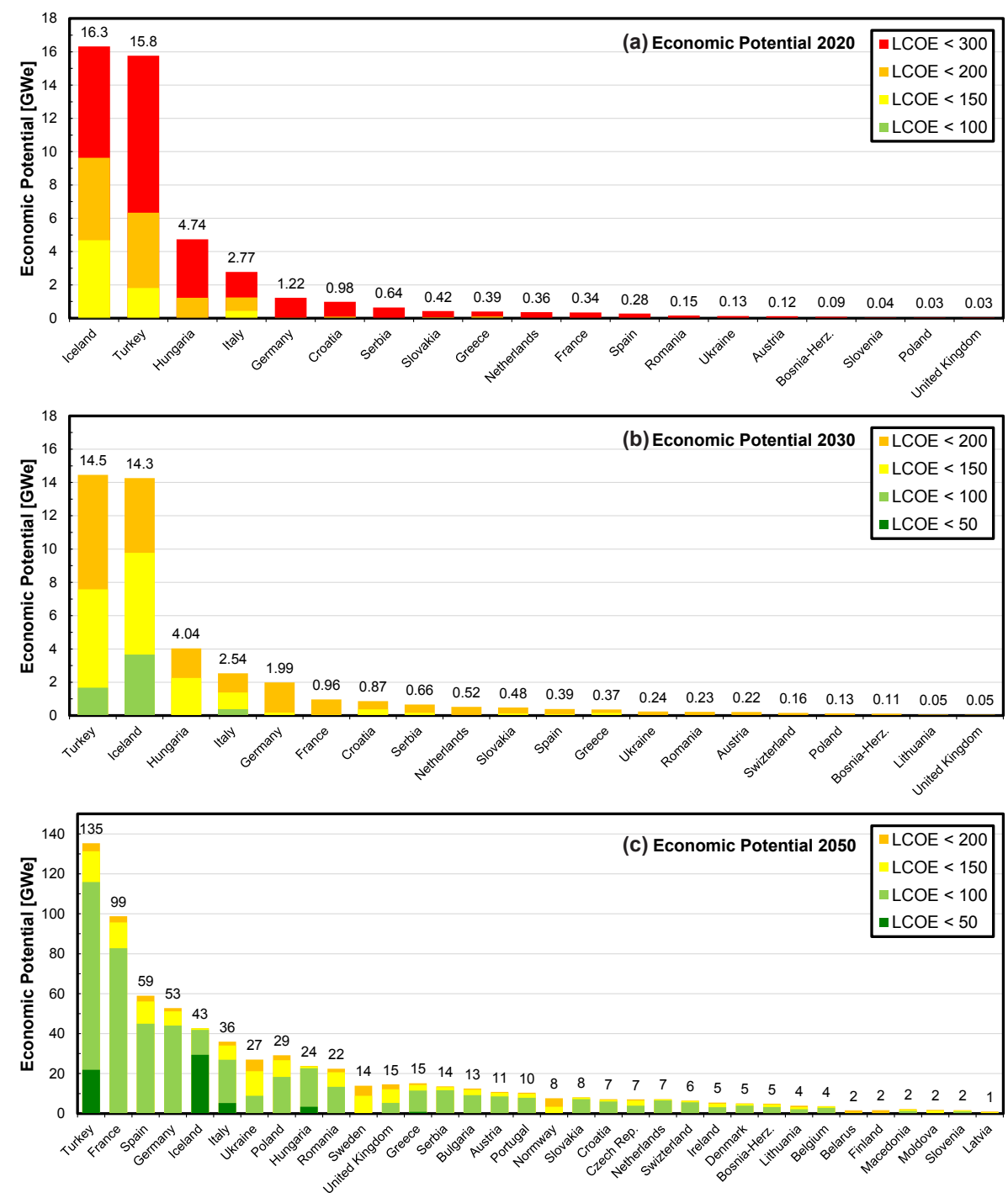

Figure 7. Economic potential in GW er country in (a) 2020, (b) 2030 and (c) 2050.

ations of relevance to European geothermal potential estimates. However, for more detailed explorative studies, the incorporation of more detailed variations of thermal properties is key to unravel the temperature structure and prospective thermal anomalies (e.g., Bonté et al., 2012).

Furthermore, it is widely recognized that locally a conductive approximation for the temperature distribution may be oversimplified and models need to take into account the effects of convective fluid flow (e.g., Bonté et al., 2012; Guillou-Frottier et al., 2013; Calcagno et al., 2014).

Improvements to the quality of the temperature model could be attained by adopting data assimilation to borehole measurements of temperature, consistent with the constitutive equations for heat transfer and fluid flow. The successful implementation of the described improvements for all of Europe can only be achieved when the quality, quantity and accessibility of geological information in Europe improves drastically.

One of the most important assumptions from a geological perspective is that the model uses a fixed flow rate. Since flow rate is one of the most sensitive parameters for the technical and economic performance of a geothermal system (e.g., Frick et al., 2010), care must be taken with the interpretation of the results. An ideal situation would be the use of locationspecific flow rates, taking into account favorable conditions for creating new reservoirs or enhancing existing ones, such as lithology, natural (fracture) permeability and the in situ stress.

Furthermore, no distinction has been made between national differences regarding the economic situation, legislation, regulation and stimulation. These effects could potentially be significant but it is not in the scope of this study to 
quantify these differences. Nevertheless, for future work the model can easily be adjusted to nation specific scenarios.

Comparing the future economic potential for Europe obtained in this study to the results of other large-scale resource assessments is problematic because of differences in methodologies and assumptions; however, the results in Table 3 appear to be in agreement with other estimations. (Stefansson, 2005; Bertani, 2010; Goldstein et al., 2011; Chamorro et al., 2014). 


\section{Appendix A: Input variables cash-flow model}

For the LCOE calculation, the following input variables are used depending on the specific application. Most of the input parameters use the default values as specified below, whilst the values of some variables, including the base temperature and the relative efficiency, depend on the temperatures derived from the temperature voxet.

Fluid and rock properties:

- $C p_{\text {water }}\left(\mathrm{J} \mathrm{Kg}^{-1} \mathrm{~K}^{-1}\right)=4250$ : the heat capacity of the geothermal fluid

- $\rho_{\text {water }}\left(\mathrm{Kg} \mathrm{m}^{-3}\right)=1078$ : the density of the geothermal fluid

- $C p_{\text {rock }}\left(\mathrm{J} \mathrm{Kg}^{-1} \mathrm{~K}^{-1}\right)=1000$ : the heat capacity of the reservoir rock

$-\rho_{\text {rock }}\left(\mathrm{Kg} \mathrm{m}^{-3}\right)=2500$ : the density of the reservoir rock.

Power conversion:

- $\eta_{\text {th }}(\%)=$ variable: total conversion efficiency

- $\eta_{\text {relative }}(\%)=60$ : the relative efficiency

- $T_{\mathrm{r}}\left({ }^{\circ} \mathrm{C}\right)=$ variable: $T_{\mathrm{r}}=T_{0}+80^{\circ} \mathrm{C}$

- $T_{i}\left({ }^{\circ} \mathrm{C}\right)=80$ : offset for $T_{\mathrm{r}}$.

Reservoir:

- $Q\left(1 \mathrm{~s}^{-1}\right)=100:$ flow rate

$-z(\mathrm{~m})=$ variable: along hole depth of a single well

- $T_{0}\left({ }^{\circ} \mathrm{C}\right)=$ variable: surface temperature

- $T_{x}\left({ }^{\circ} \mathrm{C}\right)=$ variable: production temperature

- $t$ (years $)=30$ : economic lifetime .

Subsurface:

- scaling factor for ThermoGIS well cost model $=1.5$

- well costs $\left(\right.$ EUR $10^{6}$ per well $)=$ variable

- stimulation and other costs $\left(\right.$ EUR $10^{6}$ per well) $=10$

- pump investment $\left(\right.$ EUR $10^{6}$ per pump $)=0.6$

- number of wells $=2$ : depends on application

- subsurface CAPEX $\left(\right.$ EUR 10 $\left.10^{6}\right)=$ variable

- maximum drilling depth $(\mathrm{m})=7000$.

Subsurface parasitic:

- $\operatorname{COP}\left(\mathrm{MW}_{\text {th }} \mathrm{MW}_{\mathrm{e}}^{-1}\right)=20$ : coefficient of performance to drive the pumps
- electricity price for driving the pumps (EUR $\left.\mathrm{MWh}_{\mathrm{e}}^{-1}\right)$ $=140$

- variable OPEX $\left(\mathrm{EUR} \mathrm{MWh}_{\mathrm{th}}{ }^{-1}\right)=$ variable.

Power temperature range used:

- outlet temperature power plant $\left({ }^{\circ} \mathrm{C}\right)=$ variable.

Power surface facilities:

- thermal power for electricity $\left(\mathrm{MW}_{\mathrm{th}}\right)=$ variable

- electric power $\left(\mathrm{MW}_{\mathrm{e}}\right)=$ variable

- power load time (hours per year) $=8000$

- power plant investment costs $\left(\right.$ EUR $\left.10^{6} \mathrm{MW}_{\mathrm{e}}{ }^{-1}\right)=3$

- power distance to grid $(\mathrm{m})=5000$

- power grid investment $\left(\mathrm{EUR}_{\mathrm{kW}}^{\mathrm{e}}{ }^{-1}\right)=80$

- power grid connection variable $\left(E U_{R} m^{-1}\right)=100$

- power plant CAPEX $\left(\right.$ EUR $\left.10^{6}\right)=$ variable

- power fixed OPEX rate $(\%)=1$

- power fixed OPEX $\left(\right.$ EUR $\left.10^{3} \mathrm{MW}_{\mathrm{e}}{ }^{-1}\right)=$ variable

- power variable OPEX $\left(\right.$ EUR MWh $\left._{\mathrm{e}}{ }^{-1}\right)=$ variable .

Fiscal stimulus:

- fiscal stimulus on lowering equity before tax (true or false $)=$ false

- percentage of CAPEX for fiscal stimulus $(\%)=0$

- legal max in allowed tax deduction $\left(\right.$ EUR $\left.10^{6}\right)=0$

- NPV (net present value) of benefit to project (EUR 106) $=$ variable.

Economics:

- inflation or discount rate $r(\%)=0 \%$

- loan rate $(\%)=6 \%$

- required return on equity $(\%)=15 \%$

- equity share in investment $(\%)=20 \%(100 \%$ minus debt share in investment)

- debt share in investment $(\%)=80 \%(100 \%$ minus equity share in investment)

$-\operatorname{tax}(\%)=25.5 \%$

- term loan (years) $=30$

- depreciation period (years) $=30$. 


\section{The Supplement related to this article is available online at doi:10.5194/-14-55-2014-supplement.}

Acknowledgements. The research leading to these results has received funding from the Intelligent Energy Europe Programme under grant agreement no. IEE/10/321 Project GeoElec and from the European Community's Seventh Framework Programme under grant agreement no. 608553 (Project IMAGE). This paper is largely based on the master's thesis of J. Limberger that described the work carried out during an internship at the Dutch Geological Survey (TNO) from April 2012 to March 2013. We thank the editor and two anonymous reviewers for their constructive comments, which have helped us to improve the manuscript.

Edited by: G. Beardsmore

Reviewed by: two anonymous referees

\section{References}

Agemar, T., Schellschmidt, R., and Schulz, R.: Subsurface temperature distribution in Germany, Geothermics, 44, 65-77, 2012.

Amante, C. and Eakins, B. W.: ETOPO1 1 Arc-Minute Global Relief Model: Procedures, Data Sources and Analysis, NOAA Technical Memorandum NESDIS NGDC-24, http://www.ngdc. noaa.gov/mgg/global/relief/ETOPO1/docs/ETOPO1.pdf, 2009.

Artemieva, I. M.: The Lithosphere: An Interdisciplinary Approach, Cambridge University Press, United Kingdom, ISBN 978-0-52184396-6, 2011.

Astolfi, M., Romano, M. C., Bombarda, P., and Macchi, E.: Binary ORC (organic Rankine cycles) power plants for the exploitation of medium-low temperature geothermal sources - Part A: Thermodynamic optimization, Energy, 66, 423-434, 2014a.

Astolfi, M., Romano, M. C., Bombarda, P., and Macchi, E.: Binary ORC (organic Rankine cycles) power plants for the exploitation of medium-low temperature geothermal sources - Part B: Techno-economic optimization, Energy, 66, 435-446, $2014 \mathrm{~b}$.

Augustine, C. R.: Hydrothermal Spallation Drilling and Advanced Energy Conversion Technologies for Engineered Geothermal Systems, Ph.D. thesis, Massachusetts Institute of Technology, http://hdl.handle.net/1721.1/51671, 2009.

Augustine, C. R.: Updated U.S. Geothermal Supply Characterization and Representation for Market Penetration Model Input, U.S. Geological Survey, http://www.nrel.gov/docs/fy12osti/ 47459.pdf, 2011.

Augustine, C. R., Young, K. R., and Anderson, A.: Updated U.S. Geothermal Supply Curve, in: Proceedings Thirty-Fifth Workshop on Geothermal Reservoir Engineering, Stanford University, Stanford, California, 2010.

Bassin, C., Laske, G., and Masters, G.: The Current Limits of Resolution for Surface Wave Tomography in North America, Eos, Trans. Amer. Geophys. Union, 81, 2000.

Baumgärtner, J.: Insheim and Landau - recent experiences with EGS technology in the Upper Rhine Graben, Oral presentation presented at ICEGS 25 May 2012, Freiburg, 2012.

Beardsmore, G. R., Rybach, L., Blackwell, D., and Baron, C.: A Protocol for Estimating and Mapping Global EGS Potential, Geoth. Res. T., 34, 301-312, 2010.
Bertani, R.: Geothermal Power Generation in the World 2005-2010 Update Report, in: Proceedings World Geothermal Congress 2010, The International Geothermal Association, Bali, Indonesia, 2010.

Blackwell, D. D., Negraru, P. T., and Richards, M. C.: Assessment of the Enhanced Geothermal System Resource Base of the United States, Nat. Resour. Res., 15, 283-308, 2007.

Bonté, D., Guillou-Frottier, L., Garibaldi, C., Bourgine, B., Lopez, S., Bouchot, V., and Lucazeau, F.: Subsurface temperature maps in French sedimentary basins: new data compilation and interpolation, B. Soc. Geol. Fr., 181, 377-390, 2010.

Bonté, D., Van Wees, J.-D., and Verweij, J. M.: Subsurface temperature of the onshore Netherlands: new temperature dataset and modelling, Geol. Mijnbouw-N. J. G., 91, 491-515, 2012.

Breede, K., Dzebisashvili, K., Liu, X., and Falcone, G.: A systematic review of enhanced (or engineered) geothermal systems: past, present and future, Geothermal Energy, 1, 1-27, 2013.

Busby, J., Kingdon, A., and Williams, J.: The measured shallow temperature field in Britain, Q. J. Eng. Geol. Hydroge., 44, 373 387, 2011.

Calcagno, P., Baujard, C., Guillou-Frottier, L., and Genter, A. D. A.: Estimation of the deep geothermal potential within the Tertiary Limagne basin (French Massif Central): An integrated 3D geological and thermal approach, Geothermics, 51, 496-508, 2014.

Chamorro, C. R., García-Cuesta, J. L., Mondéjar, M. E., and PérezMadrazo, A.: Enhanced geothermal systems in Europe: An estimation and comparison of the technical and sustainable potentials, Energy, 65, 250-263, 2014.

Clauser, C.: Radiogenic Heat Production of Rocks, in: Encyclopedia of Solid Earth Geophysics - second edition, edited by Gupta, H., chap. 15, pp. 1018-1024, Springer, Dordrecht, The Netherlands, ISBN 978-90-481-8701-0, 2011.

Cloetingh, S., Van Wees, J. D., Ziegler, P., Lenkey, L., Beekman, F., Tesauro, M., Förster, A., Norden, B., Kaban, M., Hardebol, N., Bonté, D., Genter, A., Guillou-Frottier, L., Voorde, M. T., Sokoutis, D., Willingshofer, E., Cornu, T., and Worum, G.: Lithosphere tectonics and thermo-mechanical properties: An integrated modelling approach for Enhanced Geothermal Systems exploration in Europe, Earth-Sci. Rev., 102, 159-206, 2010.

Coskun, A., Bolatturk, A., and Kanoglu, M.: Thermodynamic and economic analysis and optimization of power cycles for a medium temperature geothermal resource, Energ. Convers. Manage., 78, 39-49, 2014.

DiPippo, R.: Ideal thermal efficiency for geothermal binary plants, Geothermics, 36, 276-285, 2007.

Dumas, P., Van Wees, J.-D., Manzella, A., Nardini, I., Angelino, L., Latham, A., and Simeonova, D.: GEOELEC Report, http://www.geoelec.eu/wp-content/uploads/2014/01/ GEOELEC-report-web.pdf, 2013.

Exxon Production Research Company: Tectonic map of the world, American Association of Petroleum Geologists Foundation, 1995.

Frick, S., Kaltschmitt, M., and Schröder, G.: Life cycle assessment of geothermal binary power plants using enhanced lowtemperature reservoirs, Energy, 35, 2281-2294, 2010.

Gérard, A., Genter, A., Kohl, T., Lutz, P., Rose, P., and Rummel, .: The deep EGS (Enhanced Geothermal System) project at Soultzsous-Forêts (Alsace, France), Geothermics, 35, 473-483, 2006. 
Goldstein, B., Hiriart, G., Bertani, R., Bromley, C., GutiérrezNegrín, L., Huenges, E., Muraoka, H., Ragnarsson, A., Tester, J., and Zui, V.: in: IPCC Special Report on Renewable Energy Sources and Climate Change Mitigation, edited by Edenhofer, O., Pichs-Madruga, R., Sokona, Y., Seyboth, K., Matschoss, P., Kadner, S., Zwickel, T., Hansen, P. E. G., Schlömer, S., and von Stechow, C., chap. Geothermal Energy, pp. 401-436, Cambridge University Press, Cambridge, United Kingdom and New York, NY, USA, ISBN 978-1-107-02340-6, 2011.

Goodman, R., Jones, G. L. I., Kelly, J., Slowey, E., and O’Neill, N.: Geothermal Energy Exploitation in Ireland - Review of Current Status and Proposals for Optimising Future Utilisation, CSA report 3085/02.04, http://www.seai.ie/Archive1/Files_ Misc/FinalReport.pdf, 2004.

Guillou-Frottier, L., Carré, C., Bourgine, B., Bouchot, V., and Genter, A.: Structure of hydrothermal convection in the Upper Rhine Graben as inferred from corrected temperature data and basinscale numerical models, J. Volcanol. Geoth. Res., 256, 29-49, 2013.

Hantschel, T. and Kauerauf, A. I.: Fundamentals of Basin and Petroleum Systems Modeling, Springer Berlin Heidelberg, Germany, ISBN 978-3540723172, 2009.

Hasterok, D. and Chapman, D. S.: Heat production and geotherms for the continental lithosphere, Earth. Planet. Sc. Lett., 307, 5970, 2011.

Hijmans, R. J., Cameron, S. E., Parra, J. L., Jones, P. G., and Jarvis, A.: Very high resolution interpolated climate surfaces for global land areas, Int. J. Climatol., 25, 1965-1978, 2005.

Huenges, E., ed.: Geothermal Energy Systems - Eploration, Development, and Utilization, Wiley-VCH Verlag GmbH \& Co. KGaA, Weinheim, Germany, ISBN 978-3-527-40831-3, 2010.

Hurter, S. J. and Haenel, R., eds.: Atlas of Geothermal Resources in Europe (EUR 17811), Office for Official Publications of the European Communities, Luxemburg, ISBN 92-828-0999-4, 2002.

Jones, A. G., Plomerova, J., Korja, T., Sodoudi, F., and Spakman, W.: Europe from the bottom up: A statistical examination of the central and northern European lithosphere-asthenosphere boundary from comparing seismological and electromagnetic observations, Lithos, 120, 14-29, 2010.

Kost, C., Mayer, J. N., Thomsen, J., Hartmann, N., Senkpiel, C., Philipps, S., Nold, S., Lude, S., Saad, N., and Schlegl, T.: Levelized Cost of Electricity Renewable Energy Technologies, Fraunhofer Institute for Solar Energy Systems ISE, 2013.

Kramers, L., Wees, J. D. V., Pluymaekers, M. P. D., Kronimus, A., and Boxem, T.: Direct heat resource assessment and subsurface information systems for geothermal aquifers; the Dutch perspective, Geol. Mijnbouw-N. J. G., 91, 637-649, 2012.

Lako, P., Luxembourg, S. L., Ruiter, A. J., and in 't Groen, B.: Geothermal energy and SDE - Inventarisatie van de kosten van geothermische energie bij opname in de SDE, ECN-E-11022, http://www.ecn.nl/docs/library/report/2011/e11022.pdf, in Dutch, 2011.

Laske, G. and Masters, G.: A Global Digital Map of Sediment Thickness, EOS Transactions, American Geophysical Union, 78, 1997.

Limberger, J: European geothermal resource assessment for electricity production (GEOELEC), master's thesis, VU University Amsterdam, 2013.
Pharaoh, T. C.: Palaeozoic terranes and their lithospheric boundaries within the Trans-European Suture Zone (TESZ): a review, Tectonophysics, 314, 17-41, 1999.

Pollack, H. N. and Chapman, D. S.: On the regional variation of heat flow, geotherms, and lithospheric thickness, Tectonophysics, 38, 279-296, 1977.

REN21: Renewables 2014 Global Status Report, REN21 Secretariat, Paris, France, ISBN 978-3-9815934-2-6, 2014.

Rybach, L.: "The Future of Geothermal Energy" and Its Challenges, in: Proceedings World Geothermal Congress 2010, The International Geothermal Association, Bali, Indonesia, 2010.

Sanyal, S. K.: Sustainability and Renewability of Geothermal Power Capacity, in: Proceedings World Geothermal Congress 2005, The International Geothermal Association, Antalya, Turkey, 2005.

Sanyal, S. K., Morrow, J. W., and Butler, S. J.: Net power capacity of geothermal wells versus reservoir temperature - a practical perspective, in: Proceedings Thirty-Second Workshop on Geothermal Reservoir Engineering, Stanford University, Stanford, California, 2007.

Stefansson, V.: World Geothermal Assessment, in: Proceedings World Geothermal Congress 2005, The International Geothermal Association, Antalya, Turkey 2005, 2005.

Tesauro, M., Kaban, M. K., and Cloetingh, S. A. P. L.: EuCRUST07: A new reference model for the European crust, Geophys. Res. Lett., 35, 1-5, 2008.

Tester, J. W., ed.: The Future of Geothermal Energy - Impact of Enhanced Geothermal Systems (EGS) on the United States in the 21st Century - An assessment by an MIT-led interdisciplinary panel, Massachusetts Institute of Technology, Cambridge, USA, ISBN 0-615-13438-6, 2006.

U.S. Energy Information Administration: Annual Energy Outlook 2012 with Projections to 2035, http://www.eia.gov/forecasts/aeo/ pdf/0383(2012).pdf, 2012.

U.S. Energy Information Administration: Levelized Cost and Levelized Avoided Cost of New Generation Resources in the Annual Energy Outlook 2014, http://www.eia.gov/forecasts/aeo/ pdf/electricity_generation.pdf, 2014.

Van Oversteeg, K., Lipsey, L., Pluymaekers, M., Van Wees, J.-D., Fokker, P. A., and Spiers, C.: Fracture Permeability Assessment in Deeply Buried Carbonates and Implications for Enhanced Geothermal Systems: Inferences from a Detailed Well Study at Luttelgeest-01, The Netherlands, in: Proceedings Thirty-Eighth Workshop on Geothermal Reservoir Engineering, Stanford University, Stanford, California, 2014.

Van Wees, J.-D., Bergen, F. V., David, P., Nepveu, M., Beekman, F., Cloetingh, S., and Bonté, D.: Probabilistic tectonic heat flow modeling for basin maturation: Assessment method and applications, Mar. and Petrol. Geol., 26, 536-551, 2009.

Van Wees, J.-D., Kronimus, A., van putten, M., Pluymaekers, M. P. D., Mijnlieff, H., van Hooff, P., obdam, A., and Kramers, L.: Geothermal aquifer performance assessment for direct heat production - Methodology and application to Rotliegend aquifers, Geol. Mijnbouw-N. J. G., 91, 651-665, 2012.

Vilà, M., Fernández, M., and Jiménez-Munt, I.: Radiogenic heat production variability of some common lithological groups and its significance to lithospheric thermal modeling, Tectonophysics, 490, 152-164, 2010.

Williams, C. F., Reed, M. J., and Mariner, R. H.: A Review of Methods Applied by the U.S. Geological Survey in the Assessment 
of Identified Geothermal Resources, U.S. Geological Survey, http://pubs.usgs.gov/of/2008/1296/pdf/of2008-1296.pdf, 2008. 